\title{
Estimating Leaf Area of Big Sagebrush from Measurement of Sapwood
}

\section{DAVID GANSKOPP AND RICHARD MILLER \\ Abstract}

Wyoming big sagebrush (Artemisia tridentata subsp. wyomingensis) plants were destructively sampled in May 1984 in southeast Oregon to examine the applicability of the pipe model theory to an arid land shrub. This theory proposes that total leaf area or leaf biomass of a plant is limited by the amount of conducting tissue available to service the leaves. Basal sapwood areas were measured for 20 Wyoming big sagebrush plants and correlated with the biomass and leaf area of the supported foliage. Additional samples of leaves were collected over a 12-month period to evaluate fluctuations in leaf weight to leaf area relationships. Basal sapwood area of sagebrush stems was a reliable indicator of foliage biomass or leaf area $(r 2=0.95)$. Leaf area to weight relationships fluctuated significantly throughout the year with the most substantial changes occurring during the growing season. Although this species is an evergreen, the dynamic nature of foliage production and morphology demands intensive seasonal sampling to accurately predict leaf areas.

Many aspects of range management and research require estimates of foliage biomass or leaf area. Estimates of biomass are critical to managers charged with allocating forage resources, and researchers investigating the rates of photosynthesis or transpiration must have indices of total leaf area to expand their data to landscape levels. Direct acquisition of such data requires timeconsuming sampling proced ures and can be difficult to attain when plants support high densities of small leaves.

Several workers have correlated canopy dimensions or expressions of canopy volume of arid land shrubs with the biomass of the supported leaves and twigs (Lyon 1968, Bentley et al. 1970, Rittenhouse and Sneva 1977). Rittenhouse and Sneva (1977) focused on Wyoming big sagebrush and correlated photosynthetic biomass with 2 measures of canopy width and a measure of maximum plant height. Best fit was obtained with log transformations of both dependent and independent variables and models employing combinations of all 3 independent variables. Coefficients of determination $\left(r^{2}\right)$ ranged between 0.73 and 0.97 .

Foresters have needed similar information (Gholz et al. 1979), and within recent years have detected strong linear relationships between stem sapwood area and leaf area or leaf biomass of several species of trees from the Abies, Acer, Castanopsis, Juniperus, Picea, Pinus, Platanus, Pseudotsuga, Sequoia, and Tsuga genera (Dixon 1971, Grier and Waring 1974, Waring et al. 1977, Whitehead 1978, Rogers and Hinckley 1979, Kaufmann and Troendle 1981, Waring et al. 1982, Marchand 1984). Similar relationships have been detected in shrubs of the Acer and Rhododendron genera (Waring et al. 1977). The premise behind this relationship is that total leaf area or leaf biomass is limited by the amount of conducting tissue available to service the plant. Shinozaki et al. (1964a and 1964b) refer to this as the pipe model theory. The objective of this research was to examine the applicability of this relationship to Wyoming big sagebrush (Artemisia tridentata subsp. wyomingensis), a medium stature, broadleaf arid land shrub dominating several habitat types within the Great Basin (Hironaka et al. 1983).

Authors are range scientist, U.S. Department of Agriculture-Agricultural Research Service and associate professor, Eastern Oregon Agricultural Research Center, Squaw Buttc Station, Star Rt. 1-4.51 Hwy. 205, Burns, Oregon 97720.

This article is Technical Paper No. 7620. Oregon Agricultural Experiment Station. Manuscript accepted 14 November 1985.

\section{Materials and Methods}

Sapwood to leaf area relationships were based on destructive sampling of 20 shrubs growing on a Wyoming big sagebrushThurber's needlegrass (Stipa thurberiana) habitat type on the Squaw Butte Experiment Station in southeast Oregon. Phenology at the time of sampling was just prior to stem elongation and early leaf initiation. On 16 May 1984, crown dimensions of shrubs were recorded before harvest. Measurements to the nearest centimeter included the greatest diameter of the crown when viewed from above, a second maximum diameter perpendicular to the first, and the distance from the ground to the tallest actively growing tissue. Canopy openings were not subtracted from any dimension.

A sample of leaves was collected from each plant, sealed in a plastic bag, and preserved by freezing for later evaluations of leaf area to leaf weight relationships. Samples ranged from 0.1 to $3.5 \mathrm{~g}$ (oven dry) in weight. No attempt was made to sample a constant number of leaves or relate sample size to the dimensions of the plants. After each shrub was cut near ground level, a 2 to $5 \mathrm{~cm}$ thick cross section was removed from the lowermost portion of the stem, the basal surface marked, and each cross section sealed in a plastic bag to prevent desiccation. Cut plants were placed in large, open plastic bags and allowed to air dry for approximately 1 month. Leaves were removed from woody portions with the aid of a soft-bristled paint brush, oven dried at $60^{\circ} \mathrm{C}$ for 48 hours, and weighed to the nearest gram. In each of the following 11 months 20 shrubs were randomly selected and additional samples of leaves gathered. These samples were used to evaluate seasonal fluctuations of the leaf area to leaf weight relationships. Frozen samples were thawed in the lab, the leaves stripped from the stems and sandwiched between 2 sheets of acetate, and leaf areas measured with a $\mathrm{Li}$-Cor 3100 leaf area meter to the nearest $0.1 \mathrm{~mm}^{2}$. Samples were oven dried for 48 -hours and weighed to the nearest milligram on an analytical balance.

The lighter colored sapwood of the stem cross sections remained clearly discernible as long as sections remained moist. If a section
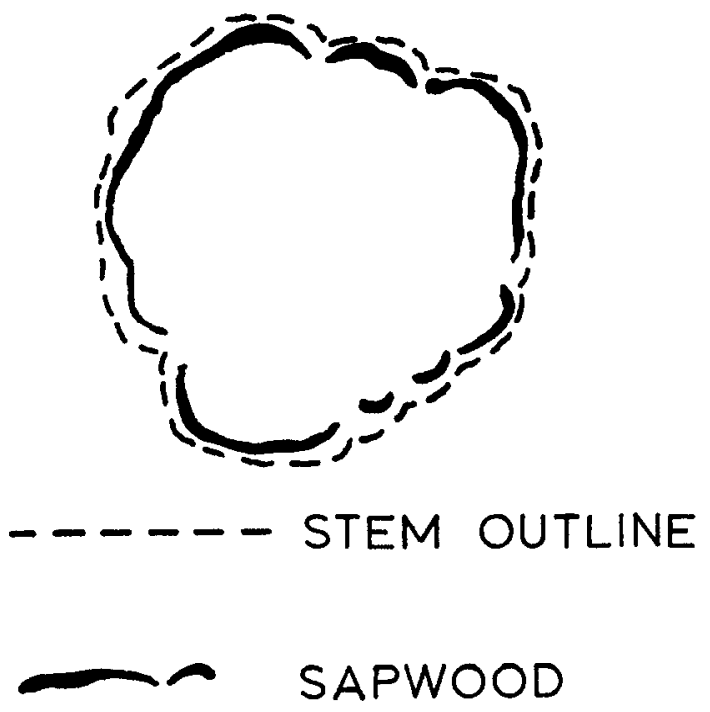

Fig. 1. Stem outline and sapwood of a Wyoming big sagebrush plant. 
dehydrated, a brief soaking in water returned the sample to its original colors. The outline of all sapwood was traced on acetate film with a fine-tipped drawing pen and the enclosed areas darkened with additional drawing ink (Fig. 1). Tracings of sapwood areas were measured with a leaf area meter to the nearest $0.1 \mathrm{~mm}^{2}$.

Linear regression was used to evaluate the relationship between leaf weight ( $x$ ) and leaf area (y) for each of the 12 months in which leaves were sampled. An F test for comparison of 2 regression lines was conducted with all possible comparisons ( 66 combinations) of the monthly regression lines (Neter and Wasserman 1974). When statistical differences were detected between lines, differences between respective slopes and intercepts were also tested (Neter and Wasserman 1974).

Dry weight values of leaves removed from shrubs in May 1984 were converted to leaf area with the May model, and linear regression used to establish the relationship between sapwood area $(x)$ and total leaf area (y) of each shrub. Appropriateness of the linear model was evaluated by examining plots of the standardized residuals and application of the Durbin-Watson test after data were ordered in accordance with the dependent variable. Following log transformations of $\mathbf{x}$ and $\mathbf{y}$ variables, stepwise regression methods were used to correlate canopy measurements of the shrubs with leaf area to compare the effectiveness of the models presented by Rittenhouse and Sneva (1977) with the sapwood derivations of the study. All statistical tests were judged significant at $P<0.05$ unless otherwise stated.

\section{Results and Discussion}

Leaf area $\left(\mathrm{cm}^{2}\right)$ per $\mathrm{cm}^{2}$ of sapwood averaged 3,200 and ranged between 1,350 and 5,220. Basal sapwood area proved to be a reliable predictor of the supported leaf area, with a linear model producing a coefficient of determination $\left(r^{2}\right)$ of 0.95 and a standard error of the estimate $\left(S_{y . x}\right)$ of $1,247 \mathrm{~cm}^{2}$ (Fig. 2). In this instance, however, we should point out that the 2 uppermost data points (Fig. 2) are very influential in estimating the slope and $r^{2}$ of the regression line. Omission of these 2 points lowered the $r^{2}$ to 0.85 and reduced the slope to 3,177 .

Models deriving leaf area from leaf weight showed significant seasonal variation throughout the year (Fig. 3 and Table 1). Of the 66 possible comparisons between monthly models, 55 comparisons proved to be significantly different. Significant variations among slopes were responsible for 53 of the 55 differences. Intercept variation was responsible for a significant difference between models in only 1 instance, i.e., models 6 and 9. Models 1 and 4 also proved to be significantly different, but individual tests of slope and intercept differences could not reject either null hypothesis.

Seasonal leaf area to leaf weight relationships may vary in response to changes in leaf morphology and development or alterations in starch and sugar accumulations. In this instance we suspect the greatest proportion of seasonal variation in leaf weight to leaf

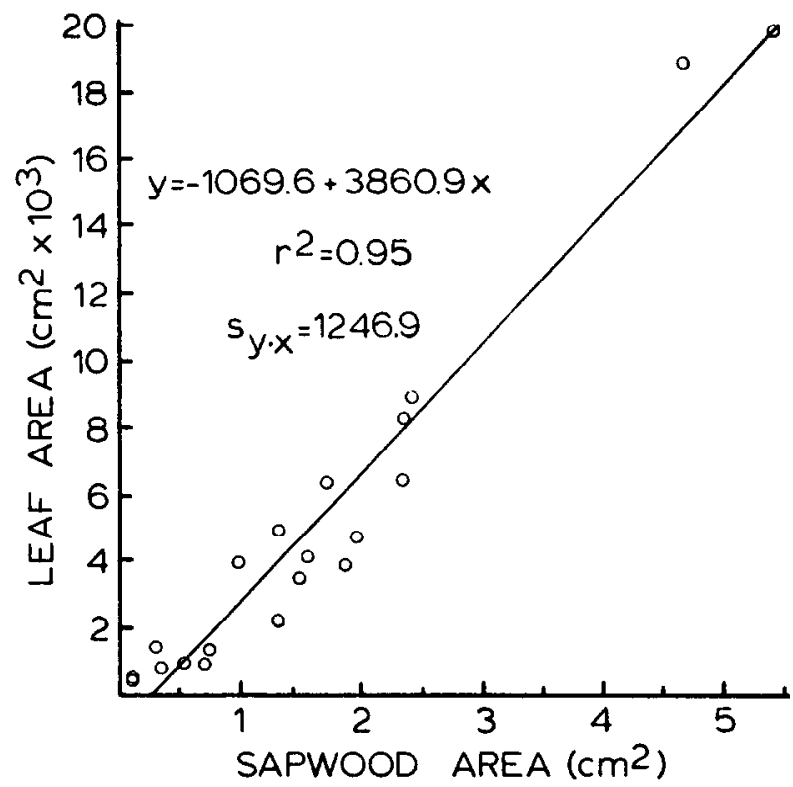

Fig. 2. Relationship of stem sapwood area to leaf area of Wyoming big sagebrush on 16 May 1984.

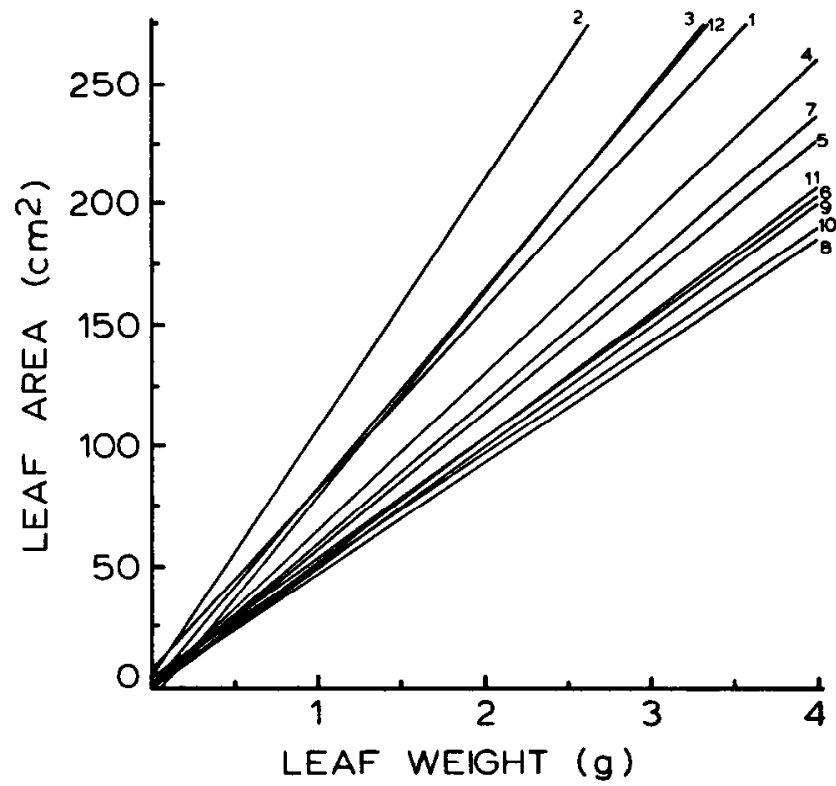

Fit. 3. Monthly relationship of leaf weight to leaf area of Wyoming big sagebrush from 1984 May (1) through 1985 April (12).

Table 1. Regression models relating leaf weight (x) to leaf area (y)from May 1984 (model 1) through April 1985 (model 12). Parameters in columns sharing common letter are not significantly different $(P>0.05)$

\begin{tabular}{|c|c|c|c|c|c|}
\hline Model number & Intercept & Slope & $r^{2}$ & Sampling date & $S_{y . x}$ \\
\hline $\begin{array}{l}1 \mathrm{a} \\
2 \\
3 \mathrm{a} \\
4 \\
5 \mathrm{~b} \\
6 \mathrm{bd} \\
7 \\
8 \\
9 \mathrm{c} \\
10 \mathrm{~cd} \\
11 \mathrm{bc} \\
12 \mathrm{a}\end{array}$ & $\begin{array}{l}7.0 \mathrm{abc} \\
4.8 \mathrm{abc} \\
-4.9 \mathrm{~b} \\
0.5 \mathrm{abc} \\
0.1 \mathrm{abc} \\
4.1 \mathrm{c} \\
1.1 \mathrm{ac} \\
1.2 \mathrm{ac} \\
-0.3 \mathrm{ab} \\
3.9 \mathrm{ac} \\
0.4 \mathrm{a} \\
0.2 \mathrm{abc}\end{array}$ & $\begin{array}{l}74.8 \mathrm{ad} \\
102.7 \\
84.1 \mathrm{a} \\
65.8 \mathrm{~d} \\
54.0 \mathrm{~b} \\
49.7 \mathrm{bc} \\
58.9 \\
46.1 \mathrm{e} \\
50.0 \mathrm{cf} \\
46.5 \mathrm{ce} \\
51.4 \mathrm{f} \\
82.2 \mathrm{a}\end{array}$ & $\begin{array}{l}0.93 \\
0.88 \\
0.99 \\
0.99 \\
0.98 \\
0.98 \\
0.99 \\
0.99 \\
0.99 \\
0.98 \\
0.99 \\
0.99\end{array}$ & $\begin{array}{l}16 \text { May } 1984 \\
22 \text { June } 1984 \\
26 \text { July } 1984 \\
24 \text { Aug. } 1984 \\
28 \text { Sep. } 1984 \\
29 \text { Oct. } 1984 \\
21 \text { Nov. } 1984 \\
24 \text { Dec. } 1984 \\
29 \text { Jan. } 1985 \\
28 \text { Feb. } 1985 \\
29 \text { Mar. } 1985 \\
29 \text { Apr. } 1984\end{array}$ & $\begin{array}{r}16.4 \\
19.7 \\
6.1 \\
6.4 \\
6.1 \\
4.3 \\
4.2 \\
2.0 \\
3.5 \\
5.7 \\
2.0 \\
8.6\end{array}$ \\
\hline
\end{tabular}


area relationships was due to the development and subsequent shedding of ephemeral leaves during the growing season. Although the various subspecies of big sagebrush are evergreen in nature, plants produce 2 types of leaves and turnover more than $50 \%$ of their leaf weight each year (Miller et al. in press). Persistent leaves are produced each spring, overwinter, and shed during the subsequent growing season. Ephemeral leaves, which are usually larger than persistent leaves, develop each spring and are shed late in the growing season when available soil moisture is greatly reduced (Daubenmire 1975, Tisdale and Hironaka 1981). In this study greatest leaf area per unit of weight was obtained from the late June sampling period when ephemeral leaves were present. Lowest leaf area per unit of weight was detected with the late December sampling when only persistent leaves were present. The data demonstrate a need to acquire frequent estimates of leaf area to leaf weight relationships throughout the year. This would be especially true during the growing season when relationships changed most rapidly.

The 20 shrubs destructively sampled range between 24 and 115 $\mathrm{cm}$ high, and from 16 to $153 \mathrm{~cm}$ across the greatest diameter of the canopy. Sampled shrubs included both decadent and vigorously growing specimens, having either single or multiple stemmed trunks and a common canopy. Models employing the log transformations of canopy measurements as independent variables produced lower coefficients of determination than the sapwood relationship (Table 2 and Fig. 2). Independent variables of $\log$

Table 2. Regression and correlation statistics relating leaf area of Wyoming big sagebrush to various crown dimensions.

\begin{tabular}{lcccc}
\hline \hline Independent variable & Intercept & $b_{1}$ & $S_{\mathbf{y} . x}$ & $r^{2}$ \\
\hline Log width 1 & -.11 & 1.90 & .183 & .87 \\
Log width 2 & -.26 & 2.22 & .184 & .87 \\
Log height & -.57 & 2.24 & .306 & .64 \\
Log [(width 1 + width 2)/2] & -1.96 & 2.06 & .178 & .88 \\
\hline
\end{tabular}

width 1 and $\log$ width 2 provided models of equivalent effectiveness, and additional combinations of the 2 variables provided only a slight improvement. Further combination of the independent variables provided no significant improvement in the models. Rittenhouse and Sneva (1977) obtained $R^{2}$ 's of 0.97 with combinations of 2 or 3 independent variables. In their work, however, openings in the canopy greater than $30 \mathrm{~cm}$ were discounted from their measurements, a procedure not employed in this study.

Due to the procedural differences a mathematical comparison between the 2 methods is not appropriate. We believe, however, the leaf area:sapwood relationship provides accurate estimates of leaf area from shrubs with decadent growth forms as well as vigorously growing specimens with closed crowns. Acquisition of canopy dimensions, when sampling sparsely occupied, disjointed crowns, could be difficult and inaccurate if numerous interspaces must be accounted for. Such considerations are unnecessary with sapwood measurements. We also hypothesize stem sapwood area would better account for changes in leaf area during the growing season than crown measurements.

Readers should be aware of 2 problems encountered in our procedures. The first difficulty was maintaining the integrity of stem cross sections composed of entwined stems. Wrapping these stems with electrician's tape or rubber bands before cutting solved this problem. The second difficulty was contamination of the airdried samples of leaves with small twigs and shredded bark. These samples could not be cleaned by screening or the use of air columns and laborious hand sorting was necessary. Most of this contamination was due to placement of large shrubs in a single large plastic bag. Extricating a dried and compacted shrub from these containers was very damaging to brittle twigs and bark. Breaking the green shrubs into smaller components, removing all materials not actually supporting foliage, and gentle handling of dried materials will greatly reduce contamination.

In summary, sapwood area can be used to make a reliable estimate of the foliage biomass or leaf area of Wyoming big sagebrush at the time of sampling. Seasonal differences in the development and shedding of persistent and ephemeral leaves of big sagebrush produces significant fluctuations in leaf weight to leaf area relationships throughout the year. The dynamic nature of these fluctuations demands that measures of leaf area of Wyoming big sagebrush be made on a seasonal basis with the most intensive sampling occurring during the growing season. Future work needs to address the suspected changes in the sapwood:leaf area relationships throughout the growing season.

\section{Literature Cited}

Bentley, J.R., D.W. Seegrist, and D.A. Blakeman. 1970. A technique for sampling low shrub vegetation by crown volume classes. U.S. Dep. of Agr. Forest Serv. Res. Note PSW-215.

Daubenmire, R.1975. Ecology of Artemisia tridentata subsp. tridentata in the state of Washington. Northwest Sci. 49:24-35.

Dixon, A.F.G. 1971. The role of aphids in wood formation. J. Appl. Ecol. 8:165-179.

Gholz, H.L., C.C. Grier, A.G. Campbell, and A.T. Brown. 1979. Equations and their use for estimating biomass and leaf area of plants in the Pacific Northwest. Forest Res. Lab., Oregon State University, Corvallis. Res. Paper 41.

Grier, C.C., and R.H. Waring. 1974. Conifer foliage mass related to sapwood area. Forest. Sci. 20:205-206.

Hironaka, M., M.A. Fosberg, and A.H. Winward. 1983. Sagebrush-grass habitat types of southern Idaho. Forest. Wildl. and Range Exp. Sta., Univ. of Idaho. Bull. 33.

Kaufmann, M.R., and C.A. Troendle. 1981. The relationship of leaf area and foliage biomass to sapwood conducting area in four subalpine forest tree species. Forest. Sci. 27:477-486.

Lyon, L.J. 1968. Estimating twig production of serviceberry from crown volumes. J. Wildl. Manage. 32:115-1 18.

Marchand, P.J. 1984. Sapwood area as an estimator of foliage biomass and projected leaf area for Abies balsamea and Picea rubens.. Can. J. Forest. Res. 14:85-87.

Miller, R.F., P.S. Doescher, T. Svecjar, and M. Haferkamp. (in press). Growth and internal water status of three subspecies of Artemisia tridentata. In: E.D. McArthur and B. Welch (ed.) Proc. Biol. of Artemisia and Chrysothamnus: Gen. Tech. Rep. INT- . USDA. Intermtn. Forest Range Exp. Sta. Ogden, Utah.

Neter, J., and W. Wasserman. 1974. Applied linear statistical models. Richard D. Irwin, Inc., Homewood, Ill.

Rittenhouse, L.R., and F.A. Sneva. 1977. A technique for estimating big sagebrush production. J. Range Manage. 30:68-70.

Rogers, R., and T.M. Hinckley. 1979. Foliar weight and area related to current sapwood area in oak. Forest. Sci. 25:298-303.

Shinozaki, K., K. Yoda, K. Hozumi, and T. Kira. 1964a. A quantitative analysis of plant form-the pipe model theory. I. Basic analyses. Jpn J. Ecol. 14:97-105.

Shinozaki, K., K. Yoda, K. Hozumi, and T. Kira. 1964b. A quantitative analysis of plant form-the pipe model theory. II. Further evidence of the theory and its application in forest ecology. Jpn. J. Ecol. 14:133-139.

Tisdale, E.W., and M. Hironaka. 1981. The sagebrush-region: a review of the ecological literature. Forest., Wild. and Range Exp. Sta., Univ. of Idaho. Bull. 33.

Waring, R.H., H.L. Gholx, C.C. Grier, M.L. Plummer. 1977. Evaluating stem conducting tissue as an estimator of leaf area in four woody angiosperms. Can. J. Bot. 55:1474-1477.

Waring, R.H., P.E. Schroder, and R. Oren. 1982. Application of the pipe model theory to predict canopy leaf area. Can. J. Forest. Res. 12:556-560.

Whitehead, D. 1978. The estimation of foliage area from sapwood basal area in Scots pine. Forestry 51:137-149. 